University of New Hampshire

University of New Hampshire Scholars' Repository

6-20-1992

\title{
A model of nitrous oxide evolution from soil driven by rainfall events: 2. Model applications
}

Changsheng $\mathrm{Li}$

University of New Hampshire - Main Campus

Steve Frolking

University of New Hampshire - Main Campus, steve.frolking@unh.edu

Tod A. Frolking

Denison University

Follow this and additional works at: https://scholars.unh.edu/earthsci_facpub

\section{Recommended Citation}

Li, C., S. Frolking, and T. A. Frolking (1992), A model of nitrous oxide evolution from soil driven by rainfall events: 2. Model applications, J. Geophys. Res., 97(D9), 9777-9783, doi:10.1029/92JD00510.

This Article is brought to you for free and open access by the Earth Sciences at University of New Hampshire Scholars' Repository. It has been accepted for inclusion in Earth Sciences Scholarship by an authorized administrator of University of New Hampshire Scholars' Repository. For more information, please contact Scholarly.Communication@unh.edu. 


\title{
A Model of Nitrous Oxide Evolution From Soil Driven by Rainfall Events: 2. Model Applications
}

\author{
Changsheng Li \\ The Bruce Company, Washington, D. C. \\ STEVE FroLKING \\ Institure for the Study of Earth, Oceans and Space, University of New Hampshire, Durham \\ TOD A. FROLKING \\ Department of Geology and Geography, Denison University, Granville, Ohio
}

\begin{abstract}
Simulations of nitrous oxide $\left(\mathrm{N}_{2} \mathrm{O}\right)$ and carbon dioxide $\left(\mathrm{CO}_{2}\right)$ emissions from soils were carried out with a rainevent model of nitrogen and carbon cycling processes in soils ( $\mathrm{Li}$ et al., this issue). Model simulations were compared with five field studies: a 1-month denitrification study of a fertilized grassland in England; a 2-month study of $\mathrm{N}_{2} \mathrm{O}$ emissions from a native and fertilized grassland in Colorado; a 1-year study of $\mathrm{N}_{2} \mathrm{O}$ emissions from agricultural fields on drained, organic soils in Florida; a 1-year study of $\mathrm{CO}_{2}$ emissions from a grassland in Germany; and a 1-year study of $\mathrm{CO}_{2}$ emissions from a cultivated agricultural site in Missouri. The trends and magnitude of simulated $\mathrm{N}_{2} \mathrm{O}$ (or $\mathrm{N}_{2} \mathrm{O}+\mathrm{N}_{2}$ ) and $\mathrm{CO}_{2}$ emissions were consistent with the results obtained in field experiments. The successful simulation of nitrous oxide and carbon dioxide emissions from the wide range of soil types studied indicates that the model, DNDC, will be a useful tool for studying linkages among climate, land use, soil-atmosphere interactions, and trace gas fluxes.
\end{abstract}

\section{INTRODUCTION}

Estimates of nitrous oxide $\left(\mathrm{N}_{2} \mathrm{O}\right)$ emissions from agricultural soils are of considerable interest because of the importance of $\mathrm{N}_{2} \mathrm{O}$ as an atmospheric trace gas and the significance of fertilized agriculture as a source of $\mathrm{N}_{2} \mathrm{O}$ to the atmosphere [Davidson, 1991]. $\mathrm{N}_{2} \mathrm{O}$ is important as a greenhouse gas; Rodhe [1990] estimates that $\mathrm{N}_{2} \mathrm{O}$ contributes about $5 \%$ of the total anthropogenic greenhouse effect. $\mathrm{N}_{2} \mathrm{O}$ has a current concentration of about 310 parts per billion by volume and is increasing at about $0.25 \%$ /year [Elkins and Rossen, 1989]. With an atmospheric lifetime of about 150 years, $\mathrm{N}_{2} \mathrm{O}$ plays an important role in the stratospheric ozone budget [Warneck, 1988]. Finally, $\mathrm{N}_{2} \mathrm{O}$ emissions are a significant pathway for the loss of nitrogen from soil [Bowden, 1986]. Emission rates could therefore be important to both ecosystem nitrogen budgets and agronomic practices.

Microbial denitrification activity is strongly dependent on decomposition processes for the production of the principal substrates, dissolved organic carbon and nitrate [e.g., Sahrawat and Keeney, 1986], and so a model of denitrification in the field should include the actions and interactions of both processes. A companion paper [ $\mathrm{Li}$ et al., this issue] describes the development, structure, and sensitivity of a rain-event model of denitrification and decomposition processes in agricultural soils. The model, denitrification and decomposition (DNDC), contains three interacting submodels. The thermal-hydraulic submodel uses soil texture, air temperature, and precipitation data to calculate soil temperature and moisture profiles and soil water

\section{Copyright 1992 by the American Geophysical Union.}

Paper number 92JD00510.

0148-0227/92/92JD-00510\$05.00 fluxes through time. This information is fed into either the denitrification submodel or the decomposition submodel. The denitrification submodel calculates hourly denitrification processes and $\mathrm{N}_{2}$ (dinitrogen) and $\mathrm{N}_{2} \mathrm{O}$ production during wet periods. The decomposition submodel calculates daily decomposition, nitrification, ammonium volatilization processes, and $\mathrm{CO}_{2}$ production. Effects of anthropogenic activities (fertilization, tillage, amendment of manure, and other agricultural practices) are incorporated into the model. As we were unable to obtain data from a field experiment where both $\mathrm{CO}_{2}$ and $\mathrm{N}_{2} \mathrm{O}$ fluxes were measured simultaneously, in this paper we report on simulations of three field studies of denitrification $\left(\mathrm{N}_{2} \mathrm{O}\right.$ or $\left.\mathrm{N}_{2} \mathrm{O}+\mathrm{N}_{2}\right)$ emission, and simulations of two field studies of soil $\mathrm{CO}_{2}$ emissions, which we consider to be an indicator of soil carbon dynamics during decomposition.

\section{MODEL APPLICATIONS}

Five field studies were chosen to validate the DNDC model: (1) a 1979 field study of $\mathrm{N}_{2} \mathrm{O}$ emissions from a native shortgrass prairie (control and urea fertilized) near Fort Collins, Colorado [Mosier et al., 1981]; (2) a 1979 field study of $\mathrm{N}_{2} \mathrm{O}$ emissions from drained, cultivated organic soils in Belle Glade, Florida [Terry et al., 1981]; (3) a 1980 field study of denitrification loss from a grassland soil in a field receiving different rates of nitrogen fertilizer in Berkshire, England [Ryden, 1983]; (4) a 1979 field study of $\mathrm{CO}_{2}$ emissions from an uncultivated grassland in Heidelberg, Germany [Dorr and Munnich, 1987]; and (5) a 1982 field study of $\mathrm{CO}_{2}$ emissions from a tilled and fertilized winter wheat field in Columbia, Missouri [Buyanovsky et al., 1986]. These environments represent a wide range of soil characteristics and thus a significant challenge to the model. A summary of the input parameters and simulation results for each of the tests follows. 


\subsection{Case 1: $\mathrm{N}_{2} \mathrm{O}$ Emissions From Prairie in Colorado}

Field measurements of $\mathrm{N}_{\mathbf{2}} \mathrm{O}$ emissions were carried out by Mosier et al. [1981] in a native shortgrass prairie from June 21 to August 22, 1979. The study site was located in the Central Plains Experimental Range, $56 \mathrm{~km}$ northeast of Fort Collins, Colorado. The soil type was Olney fine sandy loam; bulk density is $1.2 \mathrm{~g} / \mathrm{cm}^{3} ; \mathrm{pH}$ is 7 ; organic carbon content is $0.0057 \mathrm{~kg} \mathrm{C} / \mathrm{kg}$ soil; nitrate $\left(\mathrm{NO}_{3}^{-}\right)$content is $1.6 \mathrm{~kg} \mathrm{~N} / \mathrm{ha}$; and ammonium $\left(\mathrm{NH}_{4}^{+}\right)$content is $2.3 \mathrm{~kg} \mathrm{~N} / \mathrm{ha}$ [Mosier et al., 1981; Parton et al., 1988]. Urea equivalent to $450 \mathrm{~kg}$ N/ha was added uniformly to the surface of treatment plots in $\mathbf{1 . 5}$ $\mathrm{cm}$ of irrigation water at the beginning of the field experiment period. Nothing was added to the control plots. Four rainfall events (greater than $1 \mathrm{~cm}$ ) and one irrigation event occurred during the experiment (Table 1).

The emissions of $\mathrm{N}_{2} \mathrm{O}$ generally increased with the increase of rainfall flux (Figure 1). The modeled $\mathrm{N}_{2} \mathrm{O}$ peaks following rain events tend to be much sharper and to occur more quickly than the measured flux peaks. This is also true in the other denitrification studies and is discussed in section 3. Significantly, in the model simulation for the unfertilized soil, $\mathrm{N}_{2} \mathrm{O}$ emission during rainfall event 3 was lower than that in rainfall event 4 , although rainfall was higher in event 3 (Table 1). Field measurements show the two rain events to have similar $\mathrm{N}_{2} \mathrm{O}$ emissions (Figure 1). The simulation records show that nitrate accumulation in the soil increased in the dry period after rainfall event 3 because of a general increase in soil moisture and bence decomposition rates. Low soil $\mathrm{NO}_{3}^{-}$in the unfertilized study led to a low ratio of $\mathrm{N}_{2} \mathrm{O} / \mathrm{N}_{2}$ emitted during rain event 3 . For the urea-treated soil, since there was sufficient $\mathrm{NO}_{3}{ }^{-}$in the soil, $\mathrm{N}_{2} \mathrm{O}$ emission during event 3 was higher than that from the unfertilized soil [Mosier et al., 1981].

\subsection{Case 2: $\mathrm{N}_{2} \mathrm{O}$ Emissions From Organic Soil in Florida}

Field measurements of $\mathrm{N}_{2} \mathrm{O}$ emissions were carried out by Terry et al. [1981] in a fallow area in Belle Glade County, Florida, over a 377-day period from April 1979 to April 1980. The soil is the Pahokee muck (a Euic Lithic Medisaprist), the most prevalent soil series in the Everglades agricultural area. Surface bulk density is $0.34 \mathrm{~g} / \mathrm{cm}^{3} ; p H$ is 5.6; and organic carbon content is $0.429 \mathrm{~kg} \mathrm{C} / \mathrm{kg}$ soil [Terry et al., 1981].

During the annual sampling period, 37 rainfall events (rainfall higher than $0.5 \mathrm{~cm}$ for each event) occurred [Terry et al., 1981; D. J. Smith, personal communication, Southeast Regional Climate Center, Florida, 1990]. No fertilizer application occurred in the sampling period. The nitrogen mineralization rate for this soil has been estimated to range from 1000 to $1500 \mathrm{~kg} \mathrm{~N} / \mathrm{ha} / \mathrm{yr}$ [Terry, 1980].

The $\mathrm{N}_{2} \mathrm{O}$ emission intensity was related to rainfall (Figure 2). Overall, the timing and relative magnitude of $\mathrm{N}_{2} \mathrm{O}$ emissions from the model simulation are consistent with the field measurements. High soil temperature, high soil moisture, and hence high decomposition rates promote high $\mathrm{N}_{2} \mathrm{O}$ emissions during the summer months. For example, the similar rainfall of events $18(11.0 \mathrm{~cm})$ and $28(11.6 \mathrm{~cm})$ produced contrasting $\mathrm{N}_{2} \mathrm{O}$ emissions of 31.8 and $8.2 \mathrm{~kg} \mathrm{~N} / \mathrm{ha}$,
TABLE 1. Simulated Emissions of $\mathrm{N}_{2} \mathrm{O}$ and $\mathrm{N}_{2}$ From Sandy Loam During Dry Period-Rainfall Cycles From June 21 to August 22, 1979, in Fort Collins, Colorado

\begin{tabular}{|c|c|c|c|c|c|c|}
\hline \multirow{2}{*}{$\begin{array}{l}\text { Dry period- } \\
\text { Rainfall } \\
\text { Cycle }\end{array}$} & \multicolumn{2}{|c|}{$\begin{array}{l}\text { Rainfall or } \\
\text { Irrigation }\end{array}$} & \multicolumn{4}{|c|}{ Emission of $N$ Gas, $\mathbf{k g}$ N/ha } \\
\hline & No. & Flux, cm & $\overline{\mathrm{N}_{2} \mathbf{O}}$ & $\mathbf{N}_{2} \mathbf{O}^{b}$ & $\mathbf{\mathbf { N } _ { 2 }}$ & $\mathrm{N}_{2} \mathrm{O}+\mathrm{N}_{2}$ \\
\hline \multicolumn{7}{|c|}{ Native Soil } \\
\hline June 21-July 4 & 1 & 2.5 & 0.0005 & 0.005 & 0.126 & 0.132 \\
\hline July 5-July 31 & 2 & 1.8 & 0.0013 & 0.022 & 0.010 & 0.033 \\
\hline Aug. 1-Aug. 10 & 3 & 6.4 & 0.0005 & 0.020 & 0.419 & 0.440 \\
\hline Aug. 11-Aug. 16 & 4 & 5.2 & 0.0003 & 0.119 & 0.350 & 0.469 \\
\hline Aug. 17-Aug. 21 & 5 & 2.1 & 0.0006 & 0.083 & 0.360 & 0.444 \\
\hline Total & & 18.0 & 0.0032 & 0.249 & 1.265 & 1.517 \\
\hline \multicolumn{7}{|c|}{ Urea Treated Soil } \\
\hline June 21-July 4 & 1 & 2.5 & 0.0200 & 0.054 & 0.139 & 0.213 \\
\hline July 5-July 31 & 2 & 1.8 & 0.0014 & 0.022 & 0.010 & 0.033 \\
\hline Aug. 1-Aug. 10 & 3 & 6.4 & 0.0005 & 0.150 & 0.053 & 0.204 \\
\hline Aug. 11-Aug. 16 & 4 & 5.2 & 0.0004 & 0.103 & 0.232 & 0.335 \\
\hline Aug. 17-Aug. 21 & 5 & 2.1 & 0.0006 & 0.069 & 0.384 & 0.454 \\
\hline Total & & 18.0 & 0.0229 & 0.398 & 0.818 & 1.239 \\
\hline
\end{tabular}

$\mathrm{N}_{2} \mathrm{O}$ evolved during nitrification.

$\mathrm{N}_{2} \mathrm{O}$ evolved during denitrification.

respectively. The simulation records show that soluble carbon concentration and $\mathrm{CO}_{2}$ emission were higher in event 18 than in event 28 (Table 2), indicating greater microbial activity. In this simulation, soluble carbon was the limiting factor for $\mathrm{N}_{2} \mathrm{O}$ evolution in most rainfall events.

\subsection{Case 3: Denitrification Loss From Grassland in England}

Total denitrification loss $\left(\mathrm{N}_{2} \mathrm{O}+\mathrm{N}_{2}\right)$ from a loam soil under a cut ryegrass sward was measured for a 30-day period from May 28 to June 28, 1980, using the acetylene-inhibition technique [Ryden, 1983]. The experimental plots were located in Berkshire, England. The soil at the study site is a loam in the Wickham series overlying London clay. In the upper $20 \mathrm{~cm}$ of the profile, $\mathrm{pH}$ is 6.3 ; bulk density is 1.06 $\mathrm{g} / \mathrm{cm}^{3}$; organic carbon content is $0.033 \mathrm{~kg} \mathrm{C} / \mathrm{kg}$ soil; and initial $\mathrm{NO}_{3}^{-}$content is $2 \mathrm{mg} \mathrm{N} / \mathrm{kg}$ soil [Ryden, 1983; Ryden and Dawson, 1982]. Twelve rainfall events occurred during the measuring period. No irrigation was applied. The air temperature averaged $17^{\circ}-18^{\circ} \mathrm{C}$. Ammonium nitrate equivalent to $125 \mathrm{~kg} \mathrm{~N} / \mathrm{ha}$ was applied at the beginning of the measuring period.

The two peaks of simulated denitrification emission are consistent with the two peaks obtained in the field experiments and show the close relationship between $\mathrm{N}_{2} \mathrm{O}+\mathrm{N}_{2}$ flux and major soil-wetting events (Figure 3 and Table 3). Again, the modeled $\mathrm{N}_{2} \mathrm{O}+\mathrm{N}_{2}$ emission rates peak and decline more rapidly than the measured rates after a major rainfall (see discussion below). The model predicts that denitrification produces most of the $\mathrm{N}_{2} \mathrm{O}$ flux (>99\%) and that most nitrogen loss through denitrification would be as $\mathrm{N}_{2} \mathrm{O}$ (>97\%), with little $\mathrm{N}_{2}$ evolved.

\subsection{Case 4: $\mathrm{CO}_{2}$ Emissions From Grassland in Germany}

Measurements of $\mathrm{CO}_{2}$ emissions from a loamy, uncultivated, grass-covered soil near Heidelberg, Germany, 

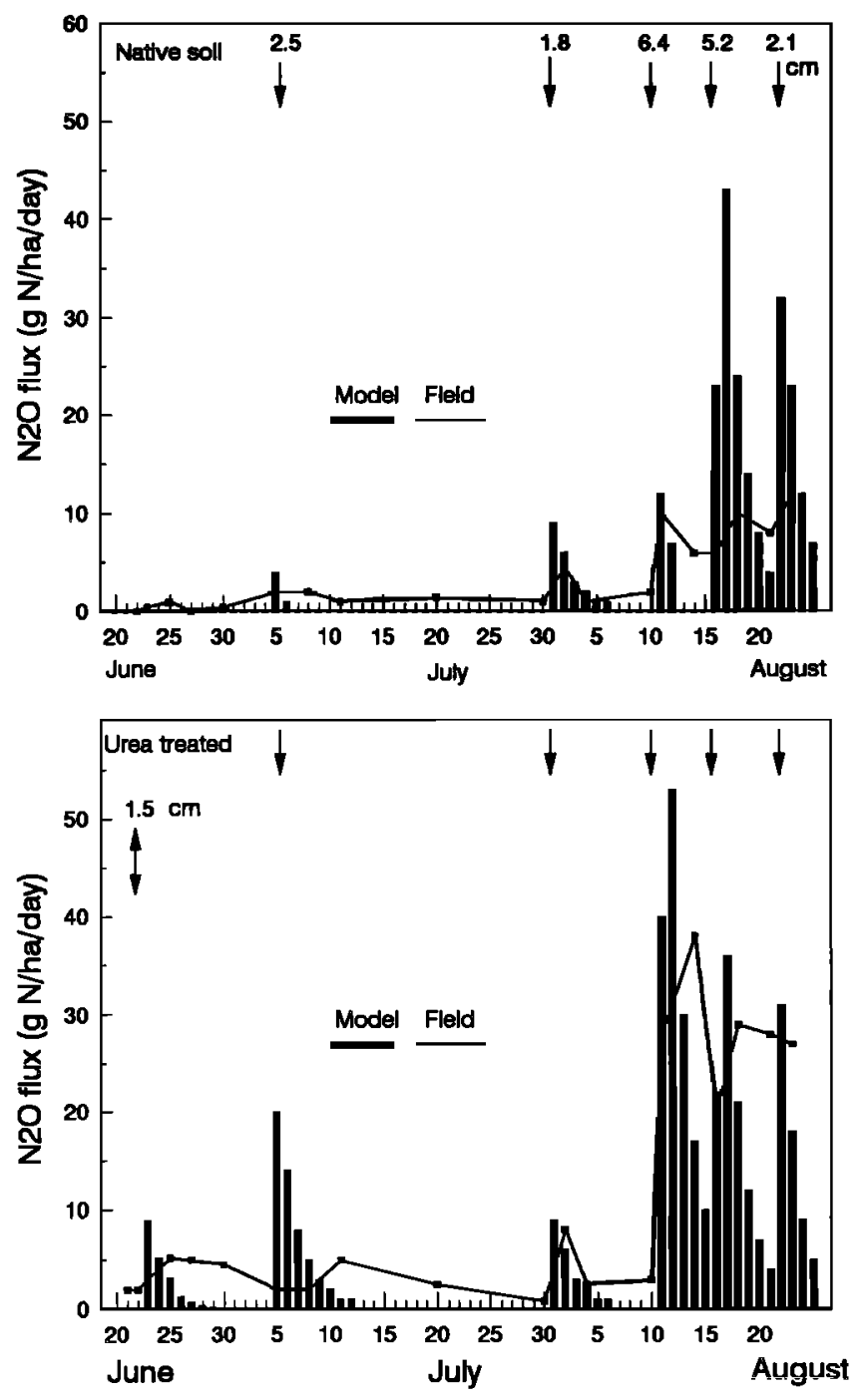

Fig. 1. Comparison of model-simulated $\mathrm{N}_{2} \mathrm{O}$ emissions with field-measured $\mathrm{N}_{2} \mathrm{O}$ emissions in Colorado in 1979 . The bars represent the simulated daily emissions of $\mathrm{N}_{2} \mathrm{O}$ from sandy loam soil in Fort Collins County, Colorado, from June 21 to August 22, 1979. The solid squares represent the $\mathrm{N}_{2} \mathrm{O}$ emissions measured in the field by Mosier et al. [1981]. The single arrows indicate timing of the five rainfall and irrigation events occurring during the sampling period; the numbers above these arrows are the amount of water in centimeters. The double arrow indicates the timing of application of urea equivalent to $450 \mathrm{~kg} \mathrm{~N} / \mathrm{ha}$ in $1.5 \mathrm{~cm}$ water. In this and the other two denitrification simulations (Figures 2 and 3 ) the model produces faster and steeper $\mathrm{N}_{2} \mathrm{O}$ peaks than are observed in the field following a rain event. This is due to the treatment of gas diffusion in the model (see discussion in text).

were carried out by Dorr and Munnich [1987] for a 1-year period in 1979 . The average daily emission rates were reported for each month of the year. Soil pH is 6.0; total organic $\mathrm{C}$ content is $0.02 \mathrm{~kg} \mathrm{C} / \mathrm{kg}$ soil. A climate scenario for the simulation was constructed from 1971 to 1980 mean monthly climate (air temperature and precipitation) for the region [United States Department of Commerce (USDC), 1987]. Briefly, a monthly scenario uses the mean monthly air temperature and an evenly spaced distribution of grade 1 (variable magnitude), grade $2(19 \mathrm{~mm})$, and grade $3(6 \mathrm{~mm})$ rainfall events. Grade 3 rainfall events have been found to have no effect on model $\mathrm{N}_{2} \mathrm{O}$ fluxes; they do not cause a large enough zone of anaerobic soil. The number of rain events per month in each class depends on the mean monthly precipitation, with the magnitude of the grade 1 rain events varying so the total monthly rain is correct. Annual total precipitation was $58.1 \mathrm{~cm}$, and annual average temperature was $8.9^{\circ} \mathrm{C}$. This mean climate scenario will certainly be different from the actual weather at the field site in 1979.

Both the simulated results and the field data show an increase in $\mathrm{CO}_{2}$ emission with warmer temperatures (Figure 4). The maximum rates were about $35-40 \mathrm{~kg} \mathrm{C} / \mathrm{ha} / \mathrm{d}$ in summer and the simulated $\mathrm{CO}_{2}$ emission rate dropped to zero in winter. The field $\mathrm{CO}_{2}$ emission rate was very low but measurable in winter. The model underestimates the spring $\mathrm{CO}_{2}$ fluxes and slightly overestimates summer fluxes but captures the strong seasonal dynamics of microbial activity. Some of the discrepancy may be due to the model's assumption that root respiration is always directly proportional to microbial activity, while spring root growth and associated respiration may cause some deviation.

\subsection{Case 5: $\mathrm{CO}_{2}$ Emissions From Winter Wheat Field in Missouri}

Measurements of $\mathrm{CO}_{2}$ emissions from a silty loam soil in a tilled and fertilized winter wheat field in Columbia, Missouri, were carried out by Buyanousky et al. [1986] in 1982. The average daily emission rates were reported for each month of the year. Total organic carbon content was $0.012 \mathrm{~kg} \mathrm{C} / \mathrm{kg}$ soil. Wheat was planted in October and harvested by the end of June. Tilling occurred before planting and after harvest. For the simulation the climate scenario was again constructed from long-term (39-year) averages [United States Department of Agriculture (USDA), 1989] and differs from the actual weather in the field in 1982. Annual average precipitation is $101.6 \mathrm{~cm}$, and annual average temperature is $12.8^{\circ} \mathrm{C}$ at the study area.

The field and simulated $\mathrm{CO}_{2}$ emission rates show similar seasonal patterns (Figure 5). With the seasonal drop in temperature, autumn emission rates decreased rapidly, but after the wheat was planted (October), $\mathrm{CO}_{2}$ emission rates increased. This increase was related to increased microbial activity following soil disturbance during planting, probably because of increased aeration and diffusion due to the breakup of a compacted surface crust. The increase in $\mathrm{CO}_{2}$ emission was significantly higher for the field measurements than the simulated results.

\section{Discussion}

Overall $\mathrm{N}_{2} \mathrm{O}$ fluxes. The simulated emissions of $\mathrm{N}_{2} \mathrm{O}$ show the same trends and similar totals to field studies in all cases (Table 4). For three of the four cases $(1 b, 2$, and 3$)$ the model underpredicts the total flux by $13-23 \%$, and for the other case ( $1 a)$ it overpredicts by about $75 \%$. Given that the total emissions for the field studies range over 3 orders of magnitude, the deviations of the model simulations are quite small. The model generally captures the timing and intensity of $\mathrm{N}_{2} \mathrm{O}$ pulses following rain events. The high peaks and short duration of $\mathrm{N}_{2} \mathrm{O}$ emissions in the simulated results could imply that the effective diffusion rates of $\mathrm{N}_{2} \mathrm{O}$ in the DNDC model are overestimated. DNDC does not model the diffusion as a gradient-driven flux with diffusion coefficients 


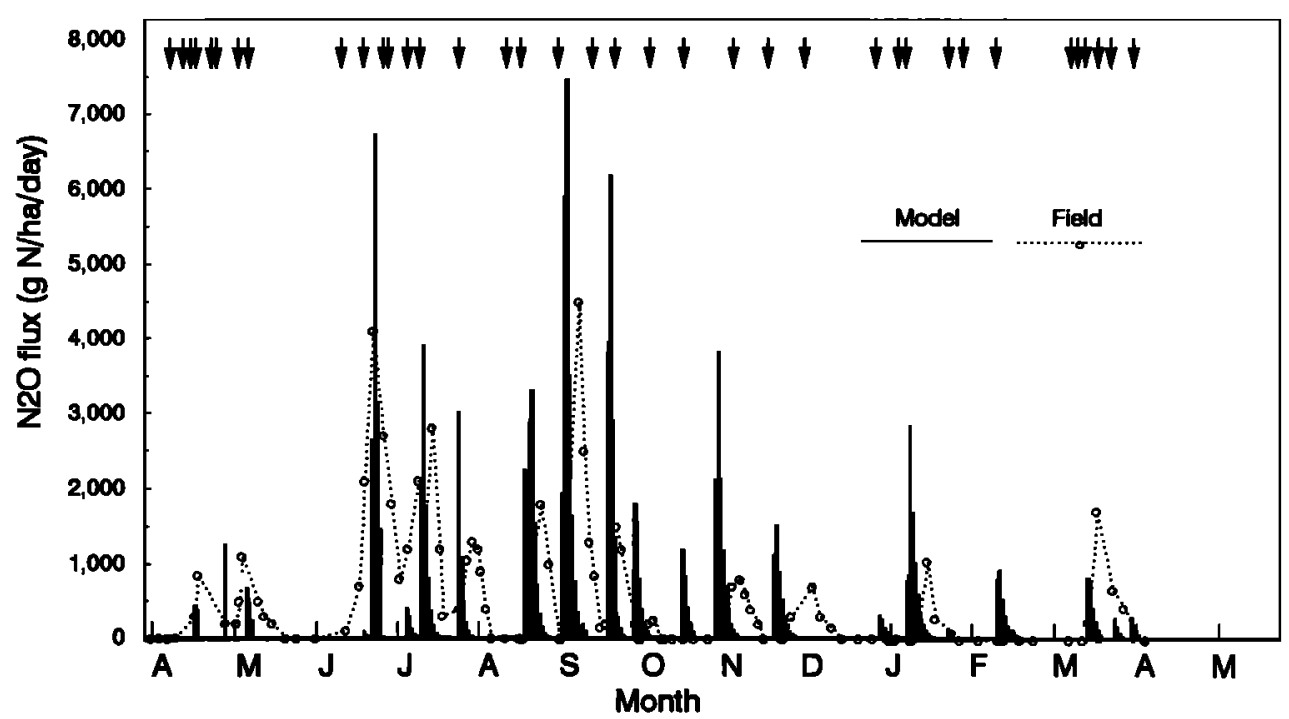

Fig. 2. Comparison of model-simulated $\mathrm{N}_{2} \mathrm{O}$ emissions with field-measured $\mathrm{N}_{2} \mathrm{O}$ emissions in Florida. The bars represent the simulated daily emissions of $\mathrm{N}_{2} \mathrm{O}$ from organic soil (muck) in Belle Glade County, Florida, from April 1979 to May 1980. The circles represent the $\mathrm{N}_{2} \mathrm{O}$ emissions measured in the field by Terry et al. [1981]. The arrows indicate the timing of the 37 rainfall events occurring during the annual sampling period.

TABLE 2. Comparison Between Rainfall Events 18 and 28 in A Fallow Area in Belle Glade County, Florida

\begin{tabular}{|c|c|c|}
\hline Item & Rainfall Event 18 & Rainfall Event 28 \\
\hline $\begin{array}{l}\text { Date } \\
\text { Rainfall } \\
\text { Temperature } \\
\mathrm{NO}_{3} \\
\text { Soluble C4 } \\
\mathrm{N}_{2} \mathrm{O} \text { emission } \\
\mathrm{N}_{2} \text { emission } \\
\mathrm{CO}_{2} \text { emission }\end{array}$ & $\begin{array}{l}\text { September 10, } 1979 \\
11.0 \mathrm{~cm} \\
26.5^{\circ} \mathrm{C} \\
1448.0 \mathrm{~kg} \mathrm{~N} / \mathrm{ha} \\
54.0 \mathrm{~kg} \mathrm{C} / \mathrm{ha} \\
31.8 \mathrm{~kg} \mathrm{~N} / \mathrm{ha} \\
2.4 \mathrm{~kg} \mathrm{~N} / \mathrm{ha} \\
3690.0 \mathrm{~kg} \mathrm{C} / \mathrm{ha}\end{array}$ & $\begin{array}{c}\text { January } 26,1979 \\
11.6 \mathrm{~cm} \\
14.7^{\circ} \mathrm{C} \\
2345.0 \mathrm{~kg} \mathrm{~N} / \mathrm{ha} \\
38.0 \mathrm{~kg} C / \mathrm{ha} \\
8.2 \mathrm{~kg} \mathrm{~N} / \mathrm{ha} \\
0.3 \mathrm{~kg} \mathrm{~N} / \mathrm{ha} \\
320.0 \mathrm{~kg} \mathrm{C} / \mathrm{ha}\end{array}$ \\
\hline
\end{tabular}

Total content in top $15 \mathrm{~cm}$ of soil profile. but rather as an empirical function of $\mathrm{N}_{2} \mathrm{O}$ production, soil moisture content, and soil clay content [ $\mathrm{Li}$ et al., this issue]. Field soils have very heterogeneous distributions of pore sizes and tortuosities, which affect both the diffusion of $\mathrm{N}_{2} \mathrm{O}$ out of the soil and the movements of moisture and oxygen to microsites within soil aggregates, where the microbial activity takes place. The current DNDC model does not account for these details of soil structure. It is also possible that the field studies, with their periodic flux measurements, may themselves be misrepresenting the detailed shape of the $\mathrm{N}_{2} \mathrm{O}$ pulse, which clearly varies rapidly with time.

Nitrification versus denitrification. In the three unfertilized

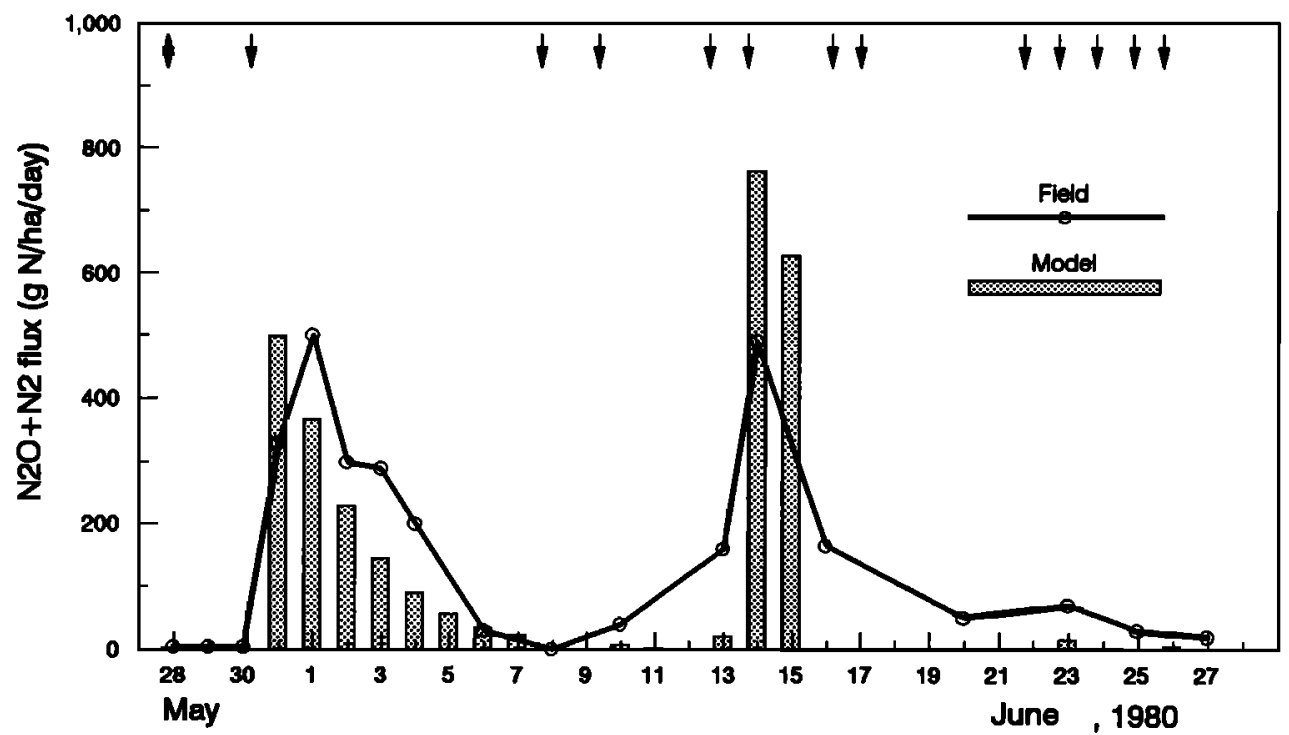

Fig. 3. Comparison of model-simulated $\mathrm{N}_{2} \mathrm{O}+\mathrm{N}_{2}$ emissions with field-measured $\mathrm{N}_{2} \mathrm{O}+\mathrm{N}_{2}$ emissions in England in 1980. The bars represent simulated daily total denitrification loss $\left(\mathrm{N}_{2} \mathrm{O}+\mathrm{N}_{2}\right)$ from loam soil in a grassland in Berkshire, England, from May 28 to June 27, 1980. Circles represent the denitrification loss measured in field by Ryden [1983]. The single arrows indicate timing of the 12 rainfall events occurring during the testing period. The double arrow indicates the timing of the application of $125 \mathrm{~kg} \mathrm{~N} / \mathrm{ha}$ as ammonium nitrate. 
cases (1a, 2, and 3) the ratio of $\mathrm{N}_{2} \mathrm{O}$ produced during nitrification to that during denitrification in the simulations ranges from 0.003 to 0.013 (Table 5). For sandy loam soil in Colorado the application of a large amount of urea $(450 \mathrm{~kg}$

TABLE 3. Simulated and Field Tested Denitrification Loss From Loam Soil in Grassland in Berkshire, England

\begin{tabular}{|c|c|c|c|c|c|c|c|}
\hline \multirow{3}{*}{$\begin{array}{l}\text { Rate } \\
1980\end{array}$} & & & \multicolumn{5}{|c|}{ Denitrification Loss, kg N/ha } \\
\hline & \multicolumn{2}{|r|}{ Rainfall } & \multicolumn{4}{|c|}{ Simulation } & \multirow{2}{*}{$\frac{\text { Field }}{\mathbf{N}_{2} \mathbf{O}+\mathbf{N}_{2}}$} \\
\hline & No. & Flux,cm & $\mathbf{N}_{2} \mathbf{O}^{*}$ & $\mathbf{N}_{2} \mathbf{O}^{b}$ & $\mathbf{N}_{2}$ & $\mathbf{N}_{2} \mathbf{O}+\mathbf{N}_{2}$ & \\
\hline May 28 & & & 0.0012 & 0 & $\mathbf{0}$ & 0.0012 & 0.005 \\
\hline 29 & & & 0.0006 & $\mathbf{0}$ & 0 & 0.0006 & 0.005 \\
\hline 30 & 1 & 1.8 & 0.0004 & 0.498 & 0 & 0.498 & 0.005 \\
\hline 31 & & & 0.0003 & 0.367 & $\mathbf{0}$ & 0.367 & 0.33 \\
\hline June 1 & & & 0.0003 & 0.230 & $\mathbf{0}$ & 0.230 & 0.50 \\
\hline 2 & & & 0.0003 & 0.144 & $\mathbf{0}$ & 0.144 & 0.30 \\
\hline 3 & & & 0.0003 & 0.090 & $\mathbf{0}$ & 0.090 & 0.29 \\
\hline 4 & & & 0.0003 & 0.056 & $\mathbf{0}$ & 0.056 & 0.20 \\
\hline 5 & & & 0.0002 & 0.035 & $\mathbf{0}$ & 0.035 & $(0.10)^{c}$ \\
\hline 6 & & & 0.0002 & 0.022 & 0 & 0.022 & 0.03 \\
\hline 7 & & & 0.0002 & 0 & 0 & 0.0002 & $(0.01)$ \\
\hline 8 & 2 & 0.2 & 0.0002 & 0 & 0 & 0.0002 & 0.005 \\
\hline 9 & & & 0.0002 & 0 & 0 & 0.0002 & $(0.005)$ \\
\hline 10 & 3 & 0.5 & 0.0002 & 0 & 0.008 & 0.008 & 0.05 \\
\hline 11 & & & 0.0002 & 0 & 0.003 & 0.003 & $(0.01)$ \\
\hline 12 & & & 0.0003 & 0 & 0.001 & 0.0013 & $(0.005)$ \\
\hline 13 & 4 & 0.6 & 0.0003 & 0.001 & 0.021 & 0.0223 & 0.17 \\
\hline 14 & 5 & 2.5 & 0.0003 & 0.764 & 0.010 & 0.774 & 0.49 \\
\hline 15 & & & 0.0003 & 0.627 & 0.005 & 0.632 & $(0.25)$ \\
\hline 16 & & & 0.0003 & 0 & 0 & 0.0003 & 0.18 \\
\hline 17 & 6 & 0.3 & 0.0003 & 0 & 0 & 0.0003 & $(0.17)$ \\
\hline 18 & 7 & 0.3 & 0.0003 & 0 & 0 & 0.0003 & 0.17 \\
\hline 19 & & & 0.0003 & 0 & 0 & 0.0003 & $(0.10)$ \\
\hline 20 & & & 0.0003 & 0 & 0 & 0.0003 & 0.05 \\
\hline 21 & & & 0.0003 & 0 & 0 & 0.0003 & $(0.05)$ \\
\hline 22 & & & 0.0003 & 0 & 0 & 0.0003 & $(0.05)$ \\
\hline 23 & 8 & 0.5 & 0.0003 & 0.001 & 0.015 & 0.016 & 0.08 \\
\hline 24 & 9 & 0.5 & 0.0003 & 0 & 0.002 & 0.0023 & $(0.05)$ \\
\hline 25 & 10 & 0.3 & 0.0003 & 0 & 0 & 0.0003 & 0.04 \\
\hline 26 & 11 & 0.7 & 0.0003 & 0 & 0.006 & 0.006 & $(0.04)$ \\
\hline 27 & 12 & 0.1 & 0.0003 & 0 & 0 & 0.0003 & 0.03 \\
\hline 28 & & & 0.0003 & 0 & 0 & 0.0003 & $(0.03)$ \\
\hline Total & & & 0.0102 & 2.835 & 0.071 & 2.916 & 3.80 \\
\hline
\end{tabular}

Produced during nitrification.

'Produced during denitrification.

'Estimated values in parentheses based on neighbors.
$\mathrm{N} / \mathrm{ha}$ ) increased the ratio to $\mathbf{0 . 0 5 8}$ (case $1 \mathrm{~b}$ ), but the ureainduced nitrification enhancement only lasted for 13 days (see Table 1). If we assume that nitrification reactions mainly occur in the surface soils $(<50 \mathrm{~cm}$ ), where organic carbon, ammonium, and nitrate are concentrated, the $\mathrm{N}_{2} \mathrm{O}$ evolved during nitrification is equal to $0.021 \mathrm{ng} / \mathrm{g} / \mathrm{d}$ soil in case $1 a$ (sandy soil in Colorado); $0.16 \mathrm{ng} / \mathrm{g} / \mathrm{d}$ in case $1 \mathrm{~b}$ (urea-treated sandy loam in Colorado); $1.3 \mathrm{ng} / \mathrm{g} / \mathrm{d}$ in case 2 (muck in Florida); and $0.15 \mathrm{ng} / \mathrm{g} / \mathrm{d}$ in case 3 (loam in England). The simulated results of $\mathrm{N}_{2} \mathrm{O}$ evolution during nitrification are generally consistent with but at the low end of the results (0.16-3.1 $\mathrm{ng} / \mathrm{g}$ soil/day) of Bremner and Blackmer [1981], Minami et al. [1978], and Bremner and Blackmer [1978]. Although application of ammonium-based fertilizers can increase $\mathrm{N}_{2} \mathrm{O}$ emission rates in nitrification, the model predicts that the total amount of $\mathrm{N}_{2} \mathrm{O}$ evolved in nitrification is still much lower than that in denitrification. In the DNDC model, nitrification-derived $\mathrm{N}_{2} \mathrm{O}$ is limited because fertilizer ammonium or urea remains in soils for only 5-6 days before most is converted into nitrate or lost to other sinks (e.g., leaching, volatilization). In contrast, in laboratory incubation studies of the soils of cases $1 a$ and $1 b$ under a range of soilwater conditions, Parton et al. [1988] find that for all but high water contents, nitrification is the dominant $\mathrm{N}_{2} \mathrm{O}$ producer. They conclude from this that nitrification must also have been the dominant $\mathrm{N}_{2} \mathrm{O}$ source in the field study because they never observed high water contents in the field. Their simulations predict nitrification to be the source of 60 $80 \%$ of the $\mathrm{N}_{2} \mathrm{O}$ emitted annually from shortgrass prairie soils.

$\mathrm{CO}_{2}$ fluxes. DNDC calculates $\mathrm{CO}_{2}$ fluxes by determining the $\mathrm{CO}_{2}$ produced during decomposition (based on laboratory rates) and then calibrates this to field measurements of total soil flux [Li et al., this issue]. The measured soil flux will include root respiration, which is not modeled. Root respiration is accounted for in the calibration factor, which is the same for all studies, and was determined using data from other field measurements [ $\mathrm{Li}$ et al., this issue]. Both modeled and measured $\mathrm{CO}_{2}$ fluxes show a marked seasonal pattern, indicating the strong temperature dependence of both the decomposition processes and the root respiration. The model tends to slightly underestimate spring $\mathrm{CO}_{2}$ fluxes in both cases (Figures 4 and 5) but captures the seasonal trend

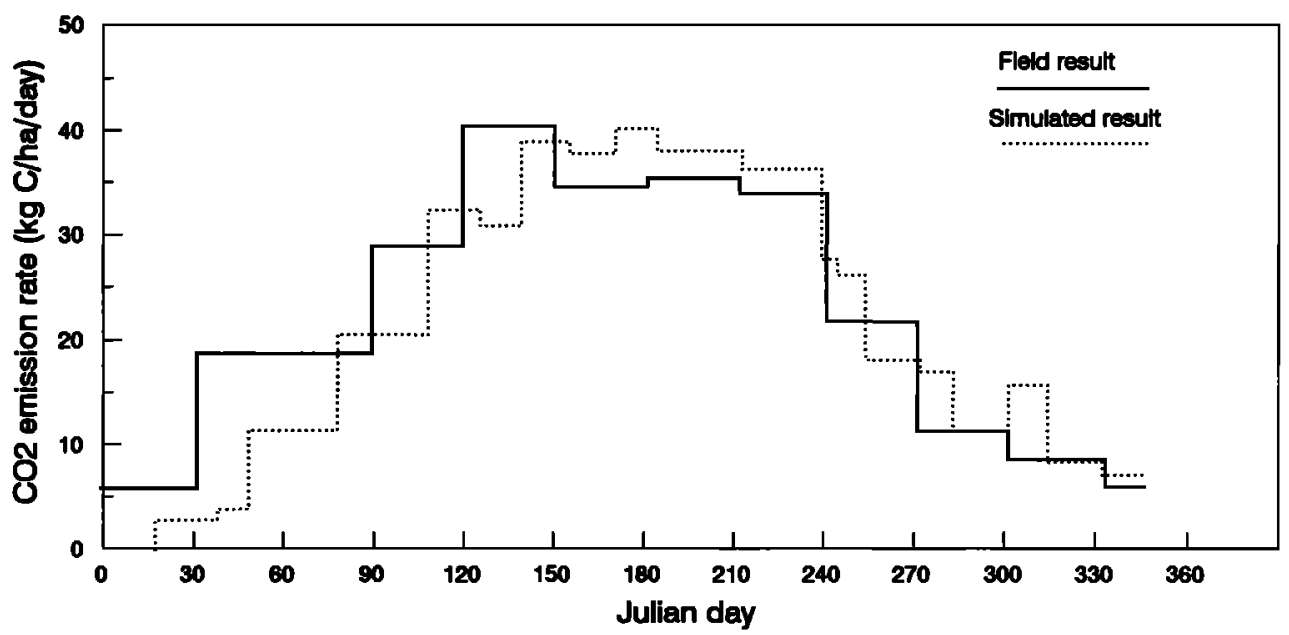

Fig. 4. Simulated and measured $\mathrm{CO}_{2}$ emissions for a grassland in Heidelberg, Germany. Both $\mathrm{CO}_{2}$ emission rates show strongly seasonal dependence. 


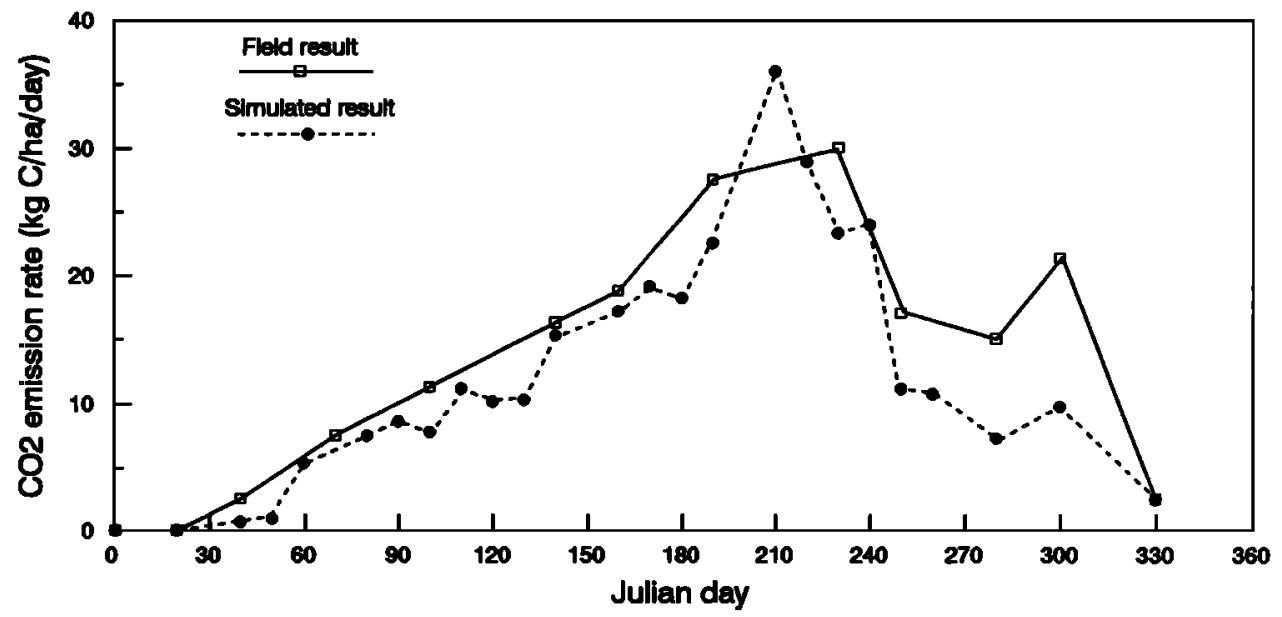

Fig. 5. Simulated and measured $\mathrm{CO}_{2}$ emissions from winter wheat field in Missouri. The model and field data differ markedly only during September and October. The increase in the $\mathrm{CO}_{2}$ emission rate in the fall is probably due to cultivation that occurred during the planting of the winter wheat crop.

TABLB 4. Comparison Between Model Simulations and Field Experiments on $\mathrm{N}_{2} \mathrm{O}$ Evolution

\begin{tabular}{llccc}
\hline & & Duration, & \multicolumn{2}{c}{$\mathrm{N}_{2} \mathrm{O}$ Evolution, $\mathrm{kg} \mathrm{N} / \mathrm{ha}$} \\
\cline { 5 - 5 } Case & Soil Type & $\begin{array}{c}\text { Day } \\
\text { Simulation }\end{array}$ & Field Test \\
\hline $1 a$ & sandy loam & 61 & 0.252 & $0.143^{b}$ \\
$1 b$ & urea treated & 61 & 0.421 & $0.493^{b}$ \\
2 & muck & 376 & 137.0 & $165.0^{\circ}$ \\
3 & loam & 32 & $2.92^{\circ}$ & $3.80^{\circ}$ \\
\end{tabular}

$\mathrm{N}_{2} \mathrm{O}+\mathrm{N}_{2}$.

Mosier et al 1981.

Terry et al 1981.

'Ryden 1982.

TABLE 5. Comparison of $\mathrm{N}_{2} \mathrm{O}$ Evolved During Nitrification And Denitrification in Model Simulations

\begin{tabular}{|c|c|c|c|c|c|}
\hline \multirow[b]{2}{*}{ Case } & \multirow[b]{2}{*}{ Soil Type } & \multirow{2}{*}{$\begin{array}{c}\text { Duration, } \\
\text { Day }\end{array}$} & \multicolumn{2}{|c|}{$\mathrm{N}_{2} \mathrm{O}$ Evolution, kg N/ha } & \multirow[b]{2}{*}{$\mathbf{A} / \mathbf{B}$} \\
\hline & & & $\mathbf{A}$ & $\overline{\mathbf{B}}$ & \\
\hline $\begin{array}{l}a \\
1 b \\
2 \\
3\end{array}$ & $\begin{array}{l}\text { sandy loam } \\
\text { urea treated } \\
\text { muck } \\
\text { loam }\end{array}$ & $\begin{array}{c}61 \\
61 \\
376 \\
32\end{array}$ & $\begin{array}{l}0.0032 \\
0.0229 \\
0.422 \\
0.0102\end{array}$ & \begin{tabular}{|c|}
0.249 \\
0.396 \\
136.7 \\
2.835
\end{tabular} & $\begin{array}{l}0.013 \\
0.058 \\
0.003 \\
0.004\end{array}$ \\
\hline
\end{tabular}

A, produced during nitrification; B, produced during denitrification.

and overall magnitude of the fluxes quite well. Some of the differences may be due to the model using a long-term mean climate, while the field results depend on the particular year's weather. Some of the differences may be due to root growth respiration, which will probably have a different seasonal signal than root maintenance respiration [Johnson, 1990].

\section{Conclusions AND FURTHER STUdIES}

As a mechanistic simulation model, DNDC uses rainfall events as a driving force to conduct monthly to annual biogeochemical simulations of soil carbon and nitrogen cycles. This model structure allows DNDC to account for the main nitrification and denitrification reactions under both aerobic and anaerobic conditions in soils and to integrate these activities with other decomposition processes during dry and wet periods to ascertain total $\mathrm{N}_{2} \mathrm{O}$ production and emission. For both $\mathrm{N}_{2} \mathrm{O}$ and $\mathrm{CO}_{2}$ emissions, DNDC behaves consistently with field reports in comprehensive, long-term simulations.

In this study, DNDC simulated $\mathrm{N}_{2} \mathrm{O}$ evolution in a wide range of soil types without changing any internal parameters. This implies that the external parameters adequately cover the major factors which influence regional variations in $\mathrm{N}_{2} \mathrm{O}$ emissions. Therefore obtaining appropriate climate and soil data becomes critical when applying DNDC to regional or global scales. For a specific area during a specific period of time, as in the five cases simulated in this study, the required external parameters may be available. But for a large region and a long time period, one must determine how to generalize the available data to formulate the required parameters, such as rainfall timing and intensity, soil properties, irrigation, fertilization, and other anthropogenic activities. More general data sources, such as national or international meteorological records and soil surveys, should be considered and compiled into a geographic information system (GIS), to which DNDC could be connected to execute regional analyses.

Acknowledgments. We wish to thank R. Harriss, J. Aber, W. Bowden, and $R$. Boone for many valuable comments and discussions. Acknowledgment is made to Climate Change Division, Office of Policy, Planning and Evaluation, United States Environmental Protection Agency, for support under grant 68-W8-0113. This work was also supported by a NASA Graduate Student Researchers Program Fellowship to Steve Frolking.

\section{REFERENCE}

Bowden, W., Gaseous nitrogen emissions from undisturbed terrestrial ecosystems: An assessment of their impacts on local and global nitrogen budgets, Biogeochemistry, 2, 249-279, 1986.

Bremner, J. M., and A. M. Blackmer, Nitrous oxide: Emission from soils during nitrification of fertilizer nitrogen, Science, 199, 295-296, 1978. 
Bremner, J. M., and A. M. Blackmer, Terrestrial nitrification as a source of atmospheric nitrous oxide, in Denifrificarion, Nitrification, and Atmospheric Nitrous Oxide, edited by C. C. Delwiche, John Wiley, New York, 1981.

Buyanovsky, G. A., G. H. Wagner, and C. J. Gantzer, Soil respiration in a winter wheat ecosystem, Soil Sci. Sac. Am. J., 50, 338-344, 1986.

Davidson, E. A., Fluxes of nitrous oxide and nitric oxide from terrestrial ecosystems, in Microbial Production and Consumption of Greenhouse Gases, edited by J. E. Rogers and W. B. Whitman, American Society Microbiology, Washington, D. C., 1991.

Dorr, E., and K. O. Munnich, Annual variation in soil respiration in selected areas of the temperate zone, Tellus, 39(B), 114-121, 1987.

Elkins, J. W., and R. Rossen, Summary Report 1988: Geophysical Monitoring for Climate Change, Natl. Oceanic and Atmos. Admin., Environ. Res. Lab., Boulder, Colo., 1989.

Johnson, I. R., Plant respiration in relation to growth, maintenance, ion uptake and nitrogen assimilation, Plant, Cell and Env., 13, 319-328, 1990.

Li, C. S., S. Frolking, and T. A. Frolking, A model of nitrous oxide evolution from soil driven by rainfall events: 1 . Model structure and sensitivity, J. Geophys. Res., this issue.

Minami, K., A. M. Blackmer, and J. M. Bremner, Emission of nitrous oxide from well-aerated soils, Agron. Abstr., p. 31, 1978.

Mosier, A. R., M. Stillwell, W. J. Parton, and R. G. Woodmansee, Nitrous oxide emissions from a native shortgrass prairie, Soil Sci. Soc. Am. J., 45, 617-619, 1981.

Parton, W. J., A. R. Mosier, and D. S. Schimel, Rates and pathways of nitrous oxide production in a shortgrass steppe, Biogeochemistry, 6, 4558, 1988.

Rodhe, H., A comparison of the contributions of various gases to the greenhouse effect, Science, 248, 1217-1219, 1990.

Ryden, J. C., Denitrification loss from grassland soil in the field receiving different rates of nitrogen as ammonium nitrate, Soil Sci., 34, $355-365,1983$.
Ryden, J. C., and K. P. Dawson, Evaluation of the acetylene-inhibition technique for the measurement of denitrification in grassland soils, J. Sci. Food Agric., 33, 1197-1206, 1982.

Sahrawat, K. L., and D. R. Keency, Nitrous oxide emissions from soils, Adv. Soll Sct., 4, 103-148, 1986.

Terry, R. B., Nitrogen mineralization in Florida histosols, Soll Sci. Soc. Am. J., 44, 747-750, 1980.

Terry, R. E., R. L. Tate III, and J. M. Duxbury, Nitrous oxide emissions from drained, cultivated organic soils of South Florida, Air Pollut. Control Assoc., 31, 1173-1176, 1981.

United States Department of Agriculture (USDA), Economic Research Service, Weather in U.S. Agriculture: Monthly Temperature and Precipitation by Stase and Farm Production Region, 1950-1988, Washington, D. C., November 1989.

United States Department of Commerce (USDC), National Oceanic and Atmospheric Administration, National Environmental Satellite, Data, and Information Service, National Climatic Data Center, World Weather Records, 1971-1980, volume 2, Europe, May 1987.

Warneck, P., The Chemistry of Natural Atmospheres, Academic, San Diego, Calif., 1988.

S. Frolking, Institute for the Study of Earth, Oceans, and Space, University of New Hampshire, Durham, NH 03824.

T. A. Frolking, Department of Geology and Geography, Denison University, Granville, OH 43023.

C. Li, The Bruce Company, 1100 6th Street, N.W., Suite 215, Washington, D. C. 20024.

(Received July 16, 1991; revised February 27, 1992; accepted February 27, 1992.) 